\title{
Simulation and Virtual Learning Environments: Tools for Teaching Psychology in Higher Education
}

\author{
Cleofé Genoveva Alvites Huamaní \\ Universidad Alas Peruanas, Lima, Perú
}

\begin{abstract}
This article provides a description of the simulation and virtual learning environments, applied in psychology. The existing literature has been reviewed: the precedents, definitions, uses, and advantages from diverse perspectives of different authors, who have applied this support tools on education. Although there are not enough studies in the psychological area, the importance of the topic suggests it is necessary to continue with this kind of investigations, which may assist as a referent to psychologists immersed in the teaching field.
\end{abstract}

Keywords: virtual environments, simulation, learning, teaching in psychology

\section{Background}

At present, the information and communication technologies have changed dramatically, especially in the teaching field. All the different options we have today in higher education, such as traditional classroom education, blended and online education, or distance learning, use these technologies. They have been changing and transforming themselves to provide students new spaces and ways of learning, virtual spaces supported by the wide range of tools that these technologies offer. In addition, our students think and process information in a different way we used to. We are dealing with digital natives, since they were born and are being raised using the internet, and the social networking websites. Chiercher, Donolo, and Corica (2013) state that these digital natives, who are now part of our classrooms, spend their lives within these two spaces: the physical and the virtual world, having a real and a digital identity. Regarding this aspect, Cabero (2010) states that technology is becoming one of the most crucial variables in the education of this knowledge society, since it allows the creation of more flexible learning environments, as well as it provides an endless amount of information. At the same time, these technologies influence our ways of understanding, processing and analyzing the world around us, and simulating and recreating real-like scenarios. Consequently, they become significant tools for training, since they enhance cognitive skills and facilitate a cognitive unity between the attitudes and skills of the individual.

Mcloughlin and Lee (2007) state that the new digital tools and their technological capabilities demand a new conceptualization of teaching, since they allow to develop skills and technological resources, whose main purposes are making students participate in learning networks, personalizing learning tasks, and producing knowledge; and abilities that students nowadays should have. Regarding this aspect, Arbelàez (2010) says it is necessary to explore new techniques intended to facilitate learning and the acquisition of knowledge. In order

Cleofé Genoveva Alvites Huamaní, Ph.D., professor and researcher at Professional Academic School of Human Psychology, Coordinator of the Research Department of the Academic Distance Education Programme, Universidad Alas Peruanas. 
to achieve this, there is a possibility to apply these technologies through three-dimensional virtual worlds, in which technology, content, and opportunities for interaction with other people, combines with recreational and instructional designs that make the immersion and simulation a suitable learning environment.

In the same way, Fernández (2009, p. 34) affirms that, "Virtual refers to everything that not even existing physically, has similar characteristics to its real reference and it even causes the actual effects this would produce". From this perspective, simulation and virtual learning environments, as learning tools in teaching, are the new training scenarios that demand pedagogical and technological challenges. Teachers and students should be able to cope with these changes, since it is another way to learn and develop the skills required in different careers. It is important to consider that this "New training system breaks the trilogy: time, space, and activity in physical locations (real)"; as a consequence, according to Chiecher et al. (2013), this leads to a change from a linear learning to learning in virtual environments, discarding the content-centered teaching, changing it by a teaching focused on personal and professional development of the student.

This new conceptualization of education has not only influenced the training of future psychologists, but also health sciences in general; in this regard, Juanes (2011) states that the technological revolution is transforming educational systems related to health sciences, since they provide useful tools for university education, allowing the creation of artificial situations, close to the real ones. Botella, Baños, García, Quero, Guillen, and Marco (2007) indicates that the use of technology and the progress it has been through, related to its application in the field of clinical psychology, will facilitate the job of health professionals, since they now have a large number of virtual tools.

\section{Simulation and Virtual Learning Environments}

Taking into account this technology-based environments, which are not new, considering that in the 20th century in 1965, Ivan Sutherland was the first to refer a computer-generated illusion. He said that a display connected to a computer gives us the chance to become familiar with concepts not realizable in the physical world. This creates a new vision to the application of technologies in a three-dimensional virtual world that simulates reality, allowing human-computer interaction. Whether this relationship occurs or not, it is important to know the answer to the following question: What are the simulation and virtual 3D learning environments?

In this regard, there are various definitions from different perspectives; some authors define them as virtual reality, such as Carmona (2012) who defines them as a virtual reality environment. This environment may be real or imaginary, and it can be visually experienced in three dimensions (width, height, and depth). Roy, Klinger, Légeron, Lauer, Chemin, and Nugues (2003) goes further, he indicates that these environments provide an interactive visual experience in real time with sound and with the possibility to add other types of feedback, such as tactile sensations. Chiecher et al. (2013) defines them as the artificial reproduction of the real world, in which students acquire psychomotor skills and knowledge, in a safe environment. Fonseca, Valdés, and Mestre (2007) define simulation and virtual learning environments as a group of computer and telematic facilities that boost communication and exchange of information in the teaching-learning process. For Salinas (2011), virtual environments are hosted educational web spaces that contain a set of tools that allow learning interaction. On the other hand, Ruiz (2012), who works in the clinical field, says that simulated environments are learning tools, whose main goal is the acquisition of skills, by training in an environment, as close as possible to a real context. This allows the students to perform activities as many times as they need in order to master a technique, without causing any harm to the patient. In this way, the margin for human error will be 
reduced, providing the students with more confidence when actually dealing with the patient. He also states that simulated environments are adequate and appropriate for the training and education of students in medical areas.

Coll (2003) points out that virtual environments are based on symbolic aspects that help boosting learning. However, they must follow the formal steps in the teaching-learning process, which are anticipating and planning of actions to be taken, emphasizing the interactivity, which allows a more active and contingent relation to information. This facilitates adaptation to different learning rhythms, and dynamism when giving the opportunity to interact with virtual realities, enabling students to explore, reflect, and experiment. García, Pericot, Gutiérrez, and Ferrer (2009) in their study about the use of technology for the treatment of smoking, defined it as the computer-based technology that generates three-dimensional environments with which the subject interacts in real time, thus producing a sense of immersion, similar to that in the real world. Fonseca et al. (2007) indicates that virtual teaching and learning environments are spaces where conditions are created so that students can get new knowledge and experiences; in other words, new elements that generate the processes of analysis, reflection, and acquisition.

Whether these environments are defined as virtual reality, simulation and learning environments or clinical simulation, the truth is that they have changed the view of the teaching-learning process in health sciences, and therefore in psychology. The implementation and use of these tools in the students training is becoming more generalized due to the benefits it provides and because they enable the development of professional skills. Bearing this in mind, it is worth noting that, as mentioned by Alvites (2012, p. 40), "The psychologist as any other professional who is involved in the teaching area, is forced to change, adapt and readjust their skills and experience to the new requirements and educational needs of these prospective professionals living in this digital generation; encouraging autonomy, and teaching them how to develop and build their own interpretations, and to rebuild culture and knowledge". In addition, we already have empirical research in psychology, applying these technologies for assessment, diagnosis, and treatment of psychological disorders; including anxiety, depression, smoking, among others. However, there is still rejection from academic psychologists to incorporate these technologies in their class sessions, as Gonzales, Montero, Pérez, and Balbuena (n. d.) corroborates, the main drawback in the use of technology for research in psychology is the resistance of the academics to simulation and the lack of preparation of psychologists in computer-related topics.

\section{Use of Simulation and Virtual Learning Environments}

The use of technology for psychological treatments dates back to 1980. At first, they were used for the treatment of phobic disorders. Regarding this, Carmona (2012) indicates that the use of virtual simulation environments offers an opportunity to study the different types of specific reactions that students may have, when they are immersed in risk situations, since they allow to recreate real-like scenarios, getting responses similar to those in real life, but in a virtual world. Therefore, there is a real possibility that these modeled scenarios, virtually simulate any circumstance similar to real life. This provides an interactive visual experience in real time, allowing the person to see, hear, and feel sensations, and believe that he is actually "there". In order to use simulation and virtual learning environments, Mestre, Fonseca, and Valdés (2007) mention that it is mandatory that these environments have telepresence, understood as the sensations result of interactions, according to the level of realism provided by the display of content in the environment. Gonzales, Montero, 
Pérez, and Balbuena (n. d.) report that a three-dimensional world created by a computer, allow us to experience the feeling of being there, which means that the brain, all the body systems, as well as the emotions react as if the invented environment was real.

Osorio, Ángel, and Franco (2012) emphasize that the use of technology through the implementation of simulated virtual environment allows the development of skills and competencies, making the students learning to do and learning to know through simulations, as well as permitting them to interact with other users' personalized identities (avatars) and three-dimensional objects. This brings students close to real-like situations, similar to the ones occurring in real context. Riofrio (2012) mentions that these environments or virtual worlds were created to train their users, since they not only increase the attention and participation of the students, but also encourage them to keep interacting with the proposed contents. Regarding this, Botella et al. (2012) indicates that these settings offer the possibility to use virtual environments as therapeutic tools in psychology since they are flexible enough to allow the design of various tailor-made scenarios for each type of disorder, in which the patient finds out that feared situations and obstacles can be overcome through confrontation and effort. Quero, Botella, Guillen, Moles, Nebot, and García-Palacios (2012) emphasize that technology is useful for treating post traumatic stress disorder, adaptative disorders and pathological grief. Botella, Quero, Serrano, Baños, and García (2009) also mention that within the field of psychology, these technologies have been applied in experimental, clinical, educational, and social psychology as well as in psychological evaluation.

\section{Advantages of Simulation and Virtual Learning Environments}

There are multiple advantages offered by these new learning environments. As Gonzales et al. (n. d.) says, virtual scenarios have a high visual quality, and allow us to use modeling and animation techniques, making the spaces and characters, that are part of the simulation, seem more realistic to the user. Arbeláez (2010) states that simulation virtual environments allow the practice and acquisition of knowledge through the implementation of case studies or real situations (which are frequently applied in psychology). In this way, students would be able to diagnose and follow good practices in the assessment, diagnosis, and treatment of patients. In the same way, he says that virtual environments facilitate learning because they are used to recreate a specific situation, allowing the design of humanizing interactive processes with educational purposes. (Johnson \& Patterson, 2007, as cited in Arbeláez, 2010) indicate that students can make mistakes in these environments and they can practice as much as they need in order to achieve the desired competencies, without harming any human being. Meanwhile, O. Tatli and Z. Tatli (2010) mentions that simulation through virtual environments allows students to follow appropriate procedures, taking into consideration the theory acquired in formal classes; and at the same time, it enhances higher levels of interpersonal confidence in the students. Aguirre (2012) points out that simulation allows the students to acquire competencies in certain procedures and skills, in a way that when dealing with their patients, they already have a real expertise. In these environments, students might be wrong when making a diagnosis. However, they are able to go over it repeatedly. Despite it is human to make mistakes, we cannot make one in health sciences, since a mistake may be fatal for the patient. Juanes (2011) remarks that simulation environments bring students close to real situations. In this way, they are far more motivated to study and learn. They also achieve satisfaction levels, evaluating the use of technology positively in their training. Another advantage, according to Ziv and Bekenstadt (2008), is that simulation environments allow the student to maximize their autonomy and ability to make decisions, making them active agents of their own learning. Moreover, they help to minimize ethical conflict. Therefore, it is imperative to use 
these environments in psychology. Quero et al. (2012) mention that clinical psychologists should have a clear understanding of the opportunities and challenges that technology offers. Virtual environments not only provide valuable opportunities related to training and self-training, but they also allow the possibility of continuing practice in a variety of contexts. This makes the user feeling he is actually "there", conceiving the situation as real. Virtual environments are also a source of personal effectiveness, since the user experience himself as a competent and effective person. They also allow the design of different scenarios in which the user can feel he is capable of performing from easy to more complex tasks. Chiecher et al. (2013) mention that these environment characteristics allow spontaneity, since learning arises at the time when it is needed. These environments are autonomous because it is the user who explores and looks for solutions. They are fast since we have immediate access to unlimited sources of information and approaches. Virtual environments are unstructured because you learn depending on the user's needs and they are specific, since they address to a specific question or problem. Another remarkable advantage of using these environments in psychological therapies, is that they allow to simulate the desired scenario when determined by the therapist. This helps to expose the user to clinically meaningful contexts as often as needed, in order to make the patient recall events and also to feedback him. In this virtual environment, the therapist can control the stimuli and events, in accordance to the type, number and intensity of the events presented. García, Pericot, Gutiérrez, and Ferrer (2009) points out the advantages of using these environments in psychological treatments, since they have two key properties such as presence and interaction. By presence we mean the feeling of "being there" in the virtual environment, in this way the patient feels he is part of this scenario. On the other hand, they recreate situations impossible to implement in the real world, with a high degree of control over the exposure techniques parameters and a high level of precision that is not possible in real contexts. In this sense, overlearning is facilitated. Thus, we can handle unwanted or threatening stimuli when presented to the patient. In this way, he would be highly motivated and involved in the therapy.

In conclusion, we can say that professional psychologists dedicated to education must be prepared to handle these technologies and apply them as a part of their class sessions, or in addition to them. Therefore, it is necessary to ensure that the contents provided in the simulation and virtual learning environment meet the basic psycho-pedagogical principles, and at the same time this information facilitates the acquisition of meaningful knowledge. Virtual environments imply a redefinition of the educational purpose and new ways to access to knowledge, enabling the development of academic programs that incorporate these simulated and virtual processes. Despite they are being used in psychotherapy, not everybody realizes its importance as a tool in the teaching-learning process. Thus, it is necessary to guide the use and application of these technologies when teaching psychology since they provide a number of advantages getting the students involved in similar scenarios that in the future they must face as prospective psychologists.

\section{References}

Alvites, C. (2012). Uso de ambientes virtuales de aprendizaje para la adquisición de competencias profesionales en el tratamiento del trastorno de ansiedad generalizada (Tesis doctoral, Facultad de Psicología, Universidad Nacional Mayor de San Marcos).

Aguirre, G. (2012). Postura experiencial de los docentes que utilizan la simulación clínica como estrategia didáctica en la carrera de medicina (Universidad Nacional de Colombia, Facultad de Ciencias Humanas).

Andreu, S. (2011). Un protocolo de tratamiento psicológico para los trastornos adaptativos apoyado por un sistema de realidad virtual: Análisis de su eficacia a través de un estudio controlado (Facultad de Ciencias Humanas y Sociales, Departamento de Psicología básica, Clínica y Psicobiología). 
Ángeles, G. O. (2003). El proceso Educativo desde los enfoques centrados en el aprendizaje en: Enfoques y modelos educativos centrados en el aprendizaje, Estado del arte y propuestas para su operativización en las instituciones de educación superior nacionales. Retrieved September 2013, from http://www.uady.mx/contadur/seccio/articulo9s/librosonline/educacion/enfoque scentradosaprendiz.pdf

Bartle, R. (2005). Virtual worlds: Why people play. Charles River Media.

Botella, C., Quero, S., Serrano, B., Baños, R., \& García, A. (2009). Avances en los tratamientos psicológicos: La utilización de las nuevas tecnologías de la información y la comunicación. Anuario de Psicologia, 40(2), 155-170.

Botella, C., Baños, R., García, A., Quero, S., Guillen, V., \& Marco, H. (2007). La utilización de las nuevas tecnologías de la información y la comunicación en psicología clínica (Vol. 4, pp. 32-41). UOC Papers: Revista Sobre La Sociedad Del Conocimiento.

Cabero, J. (2010). Los retos de la integración de las TICs en los procesos educativos: límites y posibilidades. Revista Perspectiva Educacional, 49(1). Universidad Católica de Valparaíso, Chile.

Canay, J. (2006). El uso de entornos virtuales de aprendizaje en las universidades presenciales: Un análisis empírico sobre la experiencia del campus virtual de la USC (Tesis doctoral, Facultad de Ciencias Económicas y Empresariales).

Cárdenas, G., Muñoz, S., \& González, M. (2005). Aplicaciones de la realidad virtual al tratamiento de la Agorafobia. Revista Digital Universitaria, 6(12).

Carmona, J. (2012). Aplicaciones de la simulación tridimensional para la detección precoz de consumo de sustancias y violencia escolar en ámbitos educativos: Desarrollo y validación de una herramienta informática para su detección (Tesis doctoral, Universidad de Almería, Facultad de Psicología). Retrieved from http://repositorio.ual.es/jspui/bitstream/10835/1775/1/ Doctoral\%20thesis.pdf

Chiercher, A., Donolo, D., \& Corica, J. (2013). Entornos virtuales y aprendizaje: Nuevas perspectivas de estudio e investigaciones. Compilado IV, primera edición, Mendoza, Argentina.

Coll, C. (2003). Psicología de la educación y prácticas educativas mediadas por las tecnología de la información y la comunicación: Una mirada constructivista. Sinéctica, 25, 1-24.

Fernández, R. (2009). Factores antecedentes en el uso de entornos virtuales de formación y su efecto sobre el desempeño docente. Universidad Politécnica de Valencia.

Fonseca, J., Valdés, P., \& Mestre, U. (2007). Entornos virtuales de enseñanza aprendizaje. Universidad Territorial de las Tunas, Centro de Estudios de Didáctica Universitaria.

García, E. (2012). Realidad virtual y nuevas tecnologías en el trastorno de ansiedad social:Un estudio meta-analitico (Tesis doctoral, Facultad de Psicologia, Universidad de Murcia).

García, O., Pericot, I., Gutiérrez, J., \& Ferrer, M. (2009). La realidad virtual como estrategia para la mejora de los tratamientos del tabaquismo, salud y drogas (Vol. 9, No. 1, pp. 39-55). Instituto de Investigación de Drogodependencias, España.

Gonzales, M., Montero, P., Pérez, C., \& Balbuena, L. (s/f). Generación de mundos virtuales. Universidad de Oviedo.

Guiza, M., Salinas, J., \& García-Blasquez, A. (2011). Virtual environment design for a collaborative experience among participants. In T. Bastiaens, \& M. Ebner (Eds.), Proceedings of World Conference on Educational Multimedia, Hypermedia and Telecommunications, pp. 2445-2450, Lisbon, Portugal.

Juanes, J. (2011). Nuevos entornos tecnológicos para la simulación en educación médica. XX Congreso de la Sociedad Española de Educación recuperado, November 27, 2013. Retrieved from http://www.ub.edu/medicina_unitateducaciomedica/ documentos/sedemconr esoresumen2011.pdf

Knutzen, B., \& Kennedy, D. (2012). The global classroom project: Learning a second language in a virtual environment. Electronic Journal of e-Learning, 10(1), 90-106.

Lopez, C., \& Saiegg, C. (2005). Uso de simulación como estrategia de mejora en el proceso de enseñanza-aprendizaje en las universidades, una aplicación para la carrera de informática. Universidad de Patagonia, San Juan Bosco, Facultad de Ingeniería.

McLoughlin, C., \& Lee, M. (2007). Social software and participatory learning, pedagogical choices with technology affordances in the Web 2.0 era in ICT providing choices for learners and learning proceedings, Singapore. Retrieved from http://www.ascilite.org.au/conferences/singapore07/procs/mcloughlin.pdf

Merino, J., López, E., \& Ballesteros, C. (2008). El profesor universitario en la sociedad de la información y la comunicación. Espacio y tiempo, Revista de Ciencias Humanas, 22, 213-231.

Osorio, P., Ángel, M., \& Franco, A. (2012). El uso de simuladores educativos para el desarrollo de competencias en la formación universitaria de pregrado. Revista $Q, 7(13)$. 
Prensky, M. (2001). Digital natives, digital inmigrants. In On the Horizon (Vol. 9, No. 5), NCB Press. Retrieved December 2013, from http://www.marcprensky.com/writing/Prensky\%20- 20Digital\%20Natives,\%20Digital\%20Immigrants\%20-\%20Part1. pdf

Quero, S., Botella, C., Guillen, V., Moles, M., Nebot, S., \& García-Palacios, A. (2012). La realidad virtual para el tratamiento de los trastornos emocionales: Una revisión. Anuario de Psicología Clínica y de la Salud, 8.

Riofrio, D. (2012). Diseño e implementación de un laboratorio, Facultad de Informática. Universidad Politécnica de Madrid.

Roy, S., Klinger, E., Légeron, P., Lauer, F., Chemin, I., \& Nugues, P. (2003). Cyberpsychol Behavior, 6(4), 411-420. doi:10.1089/109493103322278808

Ruiz, S. (2012). Simulación clínica y su utilidad en la mejora de la seguridad de los pacientes. Universidad Cantabria.

Salinas, M. (2011). Entornos virtuales de aprendizaje en la escuela: Tipos, modelo didáctico y rol del docente. Pontificia Universidad Católica de Argentina Retrieved from http://www.uca.edu.ar/uca/common/grupo82/files/educacion-EVA-en-laescuela_web-Depto.pdf

Silva, J. (2011). Diseño y moderación de entornos virtuales de aprendizaje. Editorial UOC Barcelona, España: Colecciòn Educaciòn y Sociedad Red.

Tatli, O., \& Tatli, Z. (2010). Simulation applications in emergency medicine education. Elsevier, Procedia-social and Behavioral Sciencies (Vol. 9, pp. 1825-1829). doi:10.1016/j.sbspro.2010.12.408

UNESCO. (2008). Estándares TIC para la formación inicial docente: Una propuesta en el contexto chileno. OREAL/UNESCO, Santiago de Chile. Retrieved from http://unesdoc.unesco.org/images/0016/001631/163149s.pdf

Vaimberg, R. (2012). Bases de la psicoterapia e intervenciones online. INTERCANVIS , 72(28).

Ziv, A., \& Berkenstadt, H. (2008). La educación médica basada en simulaciones. JANO, 1(701), 20-26. 